\title{
セラミックスの破壊靶性
}

1. は じめに

セラミックスが, 最近, New あるいはFine という形 容詞を冠してあらためて注目されている。ニュー・セラ ミックス,ないしは, ファイン・セラミックスの定義に ついては，小泉(1)や素木 ${ }^{(2)}$ らによって子解説されている が，その厳密な意味付けは難しいようである。ただ，こ れらの新しいセラミック材料が, 天然に存在する酸化物 を原料とする陶磁器や耐火物などの伝統的セラミックス に比べて特徵的なことは, 而熱性, 機械的性質, 電気 的・磁気的特性, 耐食性などの機能評価を詳細に行い, それを積極的，あるいは意識的に材料合成や設計に取入 れている点である。 その結果, 窒化物, 炭化物, 硽化物 などの新しい非酸化物系セラミックスが次々と生まれて きて怙り，航空宇宙，エレクトロニクス，医用技術など を含めた広い分野に抢けるニーズに対応すべき次世代材 料の有力候補として，アモルフォス合金などと並しで期 待が大きい，例兑ば，金属学会が 1980 年 3 月にまとめ た “金属学の未来像” (3) 飞扔いても，1573 K 以上飞耐兄 るガスタービン用材料として, $\mathrm{Si}_{3} \mathrm{~N}_{4}$ や $\mathrm{SiC}$ が有望であ るといら報告がされている．

ところで, 機械部品や構造材料などに要求される強度 といら観点からセラミックスをみた場合, 極めて硬いと いう長所を持つ半面, 脆いという短所を有しており, こ の脆さの克服，言い換觉れば，勒性の向上こそが，七ラ ミックスが単なる未来材料で終らず実用的な材料となる ための重要な課題と言える. 表 $1^{(4)}$ は各種セラミックス の代表的用途々機械的強度の重要度を示したものである が，ベアリングやエンジン部品などの工業用セラミック スや，砥粒などの工具用材料に捻いて，強度の評価と改 善が特に肝要であることがわかる。 また, 耐熱材, 原子 力関係や建筑用材料に执いてもその重要度は高い.

セラミックスの機械的性質として評価すべき項目は，

* 金沢大学助教授; 工学部精密工学科

** 金沢大学教授; 工学部精密工学科

Fracture Toughness of Ceramics ; Kanji Ueda, Tadaaki Sugita(Faculty of Eng, Kanazawa Univ, Kanazawa) 1982 年 1 月 16 日受理
上田完 次 ${ }^{*}$ 杉忠彰**

抗折力, 圧縮強度, 引張強度, 高温強度, クリープ強 度, 衝撃強度, 疲労強度, 硬度, 耐摩耗性, 破壊靶性な ぞ極めて多くのものがあげられるが，特汇重要なのは， 先にもられたように金属材料に比較してかなり劣るとさ れる破壊勒性, 拉よび, それに関連する引張強度, 熱 的・機珹的衝撃強度などであろう。セラミックスは言う までもなく組織敏感性材料であり，その強度は材料内の 気孔やき裂，異常粒子などのき裂状欠陥に大きく支配さ れる。学的に強度を取扱う場合に最も問題となるの

表 1 各種セラミックスの代表的用途と強度の重要 度 ${ }^{(4)}$.

\begin{tabular}{|c|c|c|c|}
\hline 分 類 & 材 料 & 代表的用途 & \begin{tabular}{|l} 
強度の \\
重要度
\end{tabular} \\
\hline 陶磁器類 & $\begin{array}{l}\text { 陶器, 磁器, 耐 } \\
\text { 火器 }\end{array}$ & $\begin{array}{l}\text { 食器, タイル, } \\
\text { 衛生器具, 碍子 }\end{array}$ & $*$ \\
\hline 重粘土類 & 粗粘. 陶土 & $\underset{\text { 管 }}{\text { Vガ, }}$ & $* *$ \\
\hline 砥 粒 & $\begin{array}{l}\text { アルミナ, 炭化 } \\
\text { 珪素, ダイヤモ } \\
\text { ジ }\end{array}$ & $\begin{array}{l}\text { 研削砥石, ポリ } \\
\text { シソグ剂 }\end{array}$ & $* * *$ \\
\hline 耐 熱 材 & $\begin{array}{l}\text { アルミナ, シリ } \\
\text { カ, マグネサイ } \\
\text { ド,カーボン, } \\
\text { グラフォイト }\end{array}$ & 炬材, 鋳型 & $* *$ \\
\hline ガラ ス & $\begin{array}{l}\text { ガラス, ガラス } \\
\text { セラミックス, } \\
\text { エナメル }\end{array}$ & $\begin{array}{l}\text { コンテナー, ガ } \\
\text { ラス器具, エナ } \\
\text { メル器具 }\end{array}$ & $*$ \\
\hline セメント & $\begin{array}{l}\text { ポルトランドセ } \\
\text { メント,アルミ } \\
\text { ナセメント }\end{array}$ & 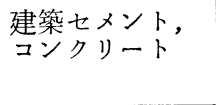 & $* *$ \\
\hline $\begin{array}{l}\text { エンジ二 } \\
\text { アリソグ. } \\
\text { セラミッ } \\
\text { クス }\end{array}$ & $\begin{array}{l}\text { 酸化物,炭化物, } \\
\text { 窒化物, サーメ } \\
\text { 学, 複合セラ } \\
\text { ミックス }\end{array}$ & $\begin{array}{l}\text { ベアリング, シ } \\
\text { ール, ダイス } \\
\text { エンジン部品 }\end{array}$ & $* * *$ \\
\hline $\begin{array}{l}\text { 電気 } \cdot \text { 磁 } \\
\text { 気・光学 } \\
\text { 材料 }\end{array}$ & 多種類 & $\begin{array}{l}\text { コソデソサ, 固 } \\
\text { 体電解質, マグ } \\
\text { ネット特殊ウ } \\
\text { インドウ }\end{array}$ & $*$ \\
\hline 原子力 & 酸化物, 炭化物 & 核燃料用 & $* *$ \\
\hline
\end{tabular}


が、これらのき裂状欠陥(以下，単にき裂と呼ぶ)近傍の 特異な応力場である。この特異な力学的応答を記述し, 解析する理論的方法論として有力なのが, Irwin (5) 以来 展開されてきた破壊力学理論である。しかしながら，七 ラミックスに対して本格的に適用されたのは比較的最近 のことであり，理論ならびに実験の両面にわたる系統的 な研究が望まれているのが現状である。

以上の上うな背景から，本稿では先ず，七ラミックス の靶性評価に有効之考兄られる破壊力学の基本的事項に ついて概説する，次いで，破壊靱性試験の実際例を紹介 するとともに，筆者らが進めている切削工具用セラミッ クスの脆性損傷に対して破壞力学を適用した解析例を示 す.

\section{2. 破壊力学の基礎的事項}

構造物や部材の強度や破壊を解析する際に, 従来のい わゆる材料力学が力学的環境パラメータとして応力 $\sigma$ やひずみをを用いるのに対して，破壊力学に执いては応 力拡大係数 $K$, ポテンシャル・エネルギ解放率 $\mathscr{C}, J$ 積 分值などを用いる。ここでは，破壊力学に扫けるこれら の基礎的事項について概説するが，詳細は例党ば文献 (6)，(7)などの成書を参照されたい。

\section{（1）き裂先端まわりの特異性と応力拡大係数 $\boldsymbol{K}$}

図 1 はき裂先端付近の座標系(平面問題)を示し, 図 2 は変形の 3 つの様式を示す。弾性論によればき裂先端近 傍の応力成分 $\sigma_{i j}$ は， $r^{-1 / 2}$ の特異性を持つ項から始まる 級数に展開され，次式の上らに表わされることが知られ ている(5).

$$
\sigma_{\mathrm{ij}}(r, \theta)=\sum_{n=-1}^{\infty} A_{\mathrm{n}}(\sqrt{r / a})^{n} f_{\mathrm{ij}, n}(\theta)(n=-1,0,1,2 \ldots)
$$

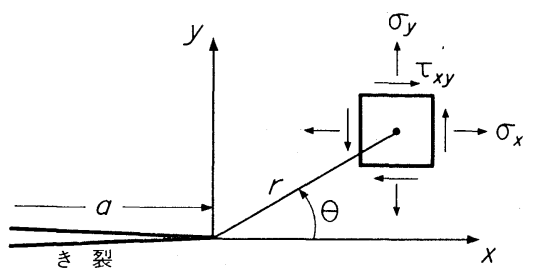

図 1 裂先端近傍の座標 (平面問題).

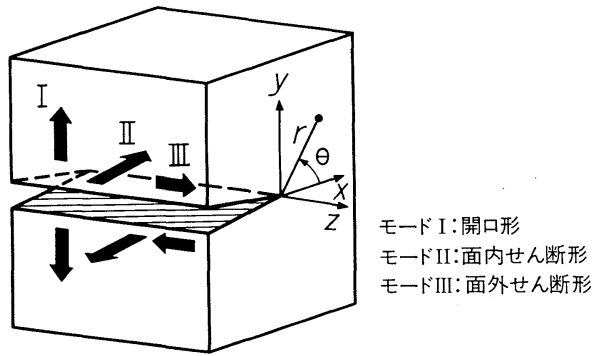

図 2 裂先端近傍の基本变形モード. ここで，aはき裂寸法， $A_{\mathrm{n}}$ は形状と外力に依存する係 数であり, $f_{\mathrm{ij}, n}$ は図 2 の各変形様式によって決まる $\theta$ の既知関数である.式 (1) から明らかなように, き裂寸法 $a$ に比べて $r$ の十分小さい範囲では，特異性を示す第 1 項で応力分布を近似することができる。図 2 のモードI (開口形)に対して， $\sigma_{\mathrm{ij}}$ を具体的飞表わすと次のように なる。

$$
\left\{\begin{array}{l}
\sigma_{x} \\
\sigma_{y} \\
\tau_{x y}
\end{array}\right\}=\frac{K_{\mathrm{I}}}{\sqrt{2 \pi r}} \cos \frac{\theta}{2}\left\{\begin{array}{r}
1-\sin \frac{\theta}{2} \sin \frac{3 \theta}{2} \\
1+\sin \frac{\theta}{2} \sin \frac{3 \theta}{2} \\
\sin \frac{\theta}{2} \cos \frac{3 \theta}{2}
\end{array}\right\}
$$

また，弾性範团内で考学ているから，变位成分 $u, v$ も KIを用いて記述できる。

$$
\left\{\begin{array}{l}
u \\
v
\end{array}\right\}=\frac{K_{\mathrm{I}}}{2 G} \sqrt{\frac{r}{2 \pi}}\left\{\begin{array}{l}
\cos \frac{\theta}{2}\left(k-1+2 \sin ^{2} \frac{\theta}{2}\right) \\
\sin \frac{\theta}{2}\left(k+1-2 \cos ^{2} \frac{\theta}{2}\right)
\end{array}\right\}
$$

ただし，u,vはそれぞれ $x, y$ 方向の変位, $G$ は奧性率で あり，係数 $k$ は平面ひずみおよび平面応力状態に対して

$$
k=\left\{\begin{array}{l}
3-4 \nu \\
(3-4 \nu) /(1+\nu) \cdots \text { 平面ひず店力 }
\end{array}\right.
$$

である.レはポアソン比である。

式(2)括よび式 (3) で用いた係数 $K$ を応力拡大係数

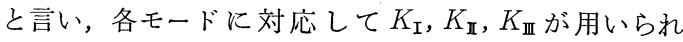
る。また，一般的な複合モードに拈ける応力場は 3 種の モードの和で記述される，ところで，応力拡大係数が問 題とする形状と負荷状態汶して決められると，き裂先 端近傍の応力, ひずみ，变位が一意的に定まることにな る。すなわち，異なるき裂先端の $K$ が互に等しい場合， 両者の弾性的な力学環境は互いに合同となる，Kは多く の例題に対して定式化されて括り，

$$
K=Y \sigma \sqrt{a}
$$

の形式で与兄られる場合が多い，ただし， $\sigma$ は遠方で生 じる一様応力, $Y$ は境界条件や負荷様式などに依存する 修正係数である。

(2) ポテンシャル・エネルギ解放率, $\mathscr{G}$

さ裂長さ $a$ を有する部材と外力の作用系からなる系全 体のポテンシャル・エネルギ $\pi$ の变化を考克る。裂成 長によるき裂面積の增加 $\mathrm{d} A$ 伴って， $\pi$ は解放され， その解放率 $\mathscr{G}$ は,

$$
\mathscr{G}=-\frac{\partial \pi}{\partial A}
$$

で表わされる。弾性応力状態に和いては，ポテンシャ ル・エネルギ解放率 $\mathscr{G}$ は応力拡大俰数 $K$ との間に次 式の関係が成立することが知られている(5).

$$
\mathscr{G}=\frac{k+1}{8 G}\left(K_{\mathrm{I}}^{2}+K_{\mathbb{I I}^{2}}\right)+\frac{1}{2 G} K_{\mathbb{I I}^{2}}
$$




\section{(3) $\boldsymbol{J}$ 皘 分值}

上記の $K$ あるいは $\mathscr{G}$ は裂先端近傍の降伏状態が 小規模の場合,すなわち, 塑性域の寸法がき裂長さや残り 断面寸法などの他の寸法に比べて十分小さい時に成立す る概念であり，その意味で線形破壊力学パラメータと呼 ぶことができる。これに対し，大規模降伏問題には Rice $^{\left({ }^{8}\right)}$ が提案した $J$ 積分值が，非線形破壊力学パラメー タとして用いられる。

図了に示すようなき裂先端を囲む曲線 $\Gamma$ に沿う線積 分

$$
J=\int_{\Gamma}\left(W * \mathrm{~d} y-\boldsymbol{T} \frac{\partial \boldsymbol{u}}{\partial x} \mathrm{~d} s\right)
$$

は積分経路 $\Gamma$ に独立で等しい值を持つ。ただし，「は 反時計まわりにとり，ds は線素の長さである。また， $W^{*}$ はひずみエネルギ密度であり， $\boldsymbol{T}$ は $\Gamma$ 上の表面力べ クトル，u恔位ベクトルである。このJ積分值の経路 独立性は非線形弾性体に沶いても成立し，その適用範囲 は弾塑性体や全面降伏問題に対しても抎張されている。

$J$ 積分值はまた，物理的にはき裂の成長に伴ら系のポテ ンシャル・エネルギの解放率といら意義を有しており， このことが $J$ 積分值の有効性を高めたと言兄る. 小規模 降伏問題に対しては，もちうんJ= $\mathscr{G}$ となる。

以上のほか飞, $\mathrm{COD}$ (き裂先端開口変位)や $\Delta K$ (応力拡 大係数の変動幅)などが破壊力学パラメータとして用い られることがある。

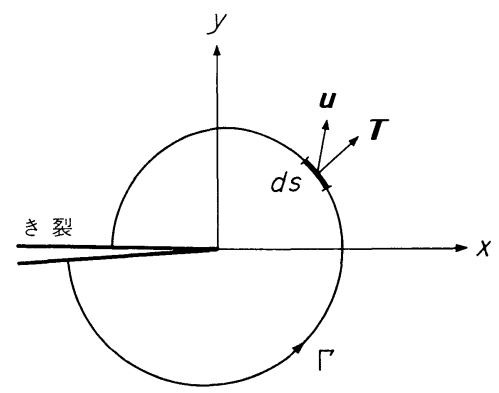

図 $3 \quad J$ 積分。

\section{3. 不安定破壊と破壊勒性}

\section{(1) 不安定破壊}

き裂を成長させるのに必要な単位面積当りのエネルギ を $\mathscr{G}_{\mathrm{c}}$ とすると,与えられた負荷条件のるとでポテンシ +ル・エネルギ解放率 $\mathscr{G}_{\text {が }} \mathscr{G}_{\mathrm{c}}$ よりる大きくなれば, き裂は加速されながら不安定的伀播し破壊に至る。 従って, エネルギ平衡の考察上り不安定破壊の条件は,

$$
\mathscr{G} \geqq \mathscr{G}_{\mathrm{c}}
$$

となる。この意味で $\mathscr{G}$ の限界值 $\mathscr{G}_{\mathrm{c}}$ を裂進展抵抗力 $R$ と呼ぶことがある。

線形破壊力学の成立範囲に扎いては，単一モードの場

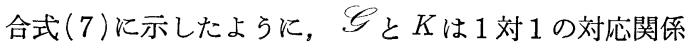
を持つから，Kの限界値 $K_{\mathrm{c}}$ を用いて，

$$
K \geqq K_{\mathbf{c}}
$$

が不安定破壊の条件式となる。

同じような考杂から，非線形問題の場合には $J$ 積分值 の限界値 $J_{\mathrm{c}}$ を用いて，

$$
J \geqq J_{\mathrm{c}}
$$

を不安定破壞の条件式とすることがある。

ところで，き裂の不安定伝播によって，脆性破壊が生 じるものと考えると，式( 9 )，式(10)，あるいは式(11) が，いわゆる材料力学港づく破壊条件 $\sigma \geqq \sigma_{\mathrm{f}} や \varepsilon \geqq \varepsilon_{\mathrm{f}}$ 飞代る脆性破壞条件となる。ここで， $\sigma_{\mathrm{f}} ， \varepsilon_{\mathrm{f}}$ はそれぞれ 破壊応力，破壊ひずみである。

上記の限界值 $K_{\mathrm{c}}, \mathscr{G}_{\mathrm{c}}$, あるいは $J_{\mathrm{c}}$ は破壊鞁性と呼 ばれ, 基本的には材料固有の值である. 特に, $K_{\mathrm{c}}$ の最 小值は平面ひずみ状態においてあらわれ，平面ひずみ破 壊靱性 $K_{\mathrm{Ic}}$ と呼び，設計上重要な值であり，多くの材 料に対して求められている.

\section{（2）破壊勒性試験}

破壊靱性を求めるために, 曲げ試験, 回転円板試験, WOL (Wedge Opening Loading) 試験, DCB (Double Cantilever Beam) 試験など各種の破壊靶性試験が提案され ているが,ここでは主に $K_{\mathrm{Ic}} 3$ 点曲げ試験と CT(Compact Tension) 試験について説明する。図 4 はASTM E-399 (9) 飞規定された $K_{\mathrm{Ic}}$ 曲げ試験片の形状・寸法を示す。同図 の試験片形状と荷重様式に対しては, 応力拡大係数は既 知であるから, 破壊発生時の荷重を $P_{\mathrm{m}}$ とすると, $K_{\mathrm{Ic}}$ は次式で与兄られる。

$$
\begin{aligned}
K_{\text {Ic }}= & \frac{P_{\mathrm{m}} S}{B W^{3 / 2}}\left[2.9(a / W)^{1 / 2}-4.6(a / W)^{3 / 2}\right. \\
& \left.+21.8(a / W)^{5 / 2}-37.6(a / W)^{7 / 2}+38.7(a / W)^{9 / 2}\right]
\end{aligned}
$$

ここで, $S$ は支点間距離, $W$ は試験片の幅, $B$ は厚さ である、また， $K_{\mathrm{Ic}}$ の值が有効であるためには，次の条 件を満たす必要がある。

$$
B a \geqq 2.5\left(K_{\mathrm{Ic}} / \sigma_{\mathrm{Y}}\right)^{2}
$$

ただし， $\sigma_{\mathrm{Y}}$ は単純引張り降伏応力である。

次に, 図 5 はCT試験片の形状を示しており,この場 合の $K_{\mathrm{Ic}}$ は次のように与光られる。

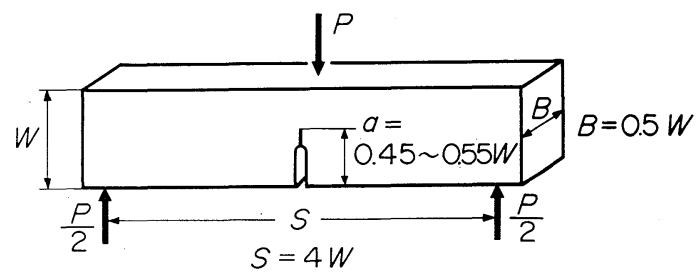

因 4 標準破壊勒性試験片 ( 3 点曲げ試験)。 


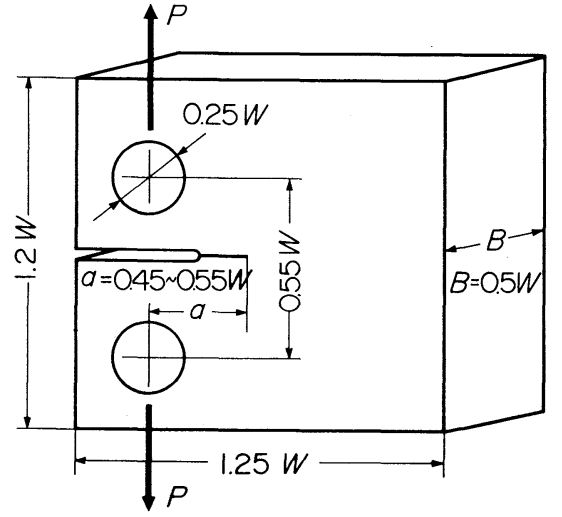

図 5 標準破壊靶性試験片 (CT 試験).

$$
\begin{aligned}
K_{\mathrm{Ic}}= & \frac{P_{\mathrm{m}}}{B W^{1 / 2}}\left[29.6(a / W)^{1 / 2}-185.5(a / W)^{3 / 2}\right. \\
& +655.7(a / W)^{5 / 2}-1017.0(a / W)^{7 / 2} \\
& \left.+638.9(a / W)^{9 / 2}\right]
\end{aligned}
$$

この時も, 式(13)の条件を満たしている必要がある.

ところで, 試験片に導入される予備き裂はその先端半 径を十分に小さくしなければならず，通常は切欠き底に 疲労によって作られる。しかしながら，七ラミックスに おいては，この方法は極めて困難であるため，図６に示 すようなヌープ圧子の押込みによって導入された表面き 裂を用いる簡便法を適用することが多い，表面き裂を半 楕円板状と仮定し，その短径と長径を各々 $2 a, 2 b$ とする と, 応力拡大係数 $K_{\mathrm{I}}$ は

$$
K_{\mathrm{I}}=M \sigma \sqrt{\pi a} / \Phi
$$

で与えられる(10). ここで， $M$ は形状に依存する補正係 数であり， $\Phi$ は楕円積分

$$
\Phi=\int_{0}^{\pi / 2}\left[1-\frac{b^{2}-a^{2}}{b^{2}} \sin ^{2} \theta\right]^{1 / 2} \mathrm{~d} \theta
$$

である。また， $\sigma$ はき裂から十分離れた遠方で生じる一 様な垂直応力であるが，公称応力を用いることが多い. この方法は比較的再現性もよくセラミックスに対しては 実用的な方法と言えよう。

また,Evans ら (11)はビッカース圧痕に発生したき裂長 さの測定より，次式を用いて破壊靶性を求める簡便法を 提案している.

$$
K_{\mathbf{c}}=\frac{0.15 k H_{\mathrm{v}}}{\theta}(a / c)^{-3 / 2 \sqrt{c}}
$$

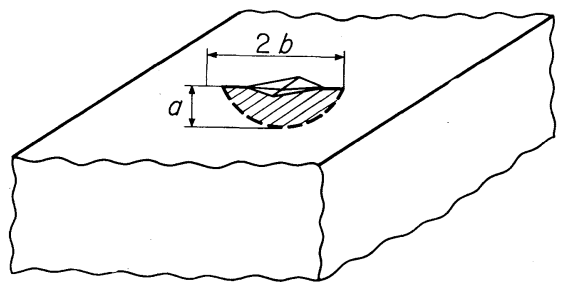

図 6 半棈円板状の表面き裂.
ただし， $a$ はビッカース痕中心から測定したき裂長さで

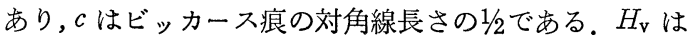
ビッカース硬度, $k$ は実験的に求められる係数であり, $\theta$ は 3 に近い定数である。この方法は破壊試験を行う必 要がなく，非常に簡便な方法と言えるが，係数を実験的 に求めていることや破壊勒性は $K_{\mathrm{Ic}}$ でなく $K_{\mathrm{c}}$ であるこ となどに注意する必要がある。

\section{（3）セラミックスの破壊勒性の例}

各種セラミックスの室温に打ける破壊靱性 $K_{\mathrm{c}}$ の測定 例を表 $2^{(11) \sim(15)}$ に示す. また. 参考のために金属材料 の破壊勒性の代表例を表 $3^{(6)}$ に示す．全般的にセラミッ クスは金属材料に比較して破壊靱性が極めて低いのがわ かる. 表 2 のラミックスの中で最も靱性に富むのは, 結合相としての Co を含むWC-Co 系超硬合金でその破 壊靱性は $12 \sim 16 \mathrm{MN} / \mathrm{m}^{3 / 2}$ であるが，それでも高力アル ミニウム合金やチタニウム合金に比べても $1 / 2$ 以下，炭素 鋼などと比較すると1/10以下となり非常に小さい．他のセ ラミックスにおいてはさらに金属材料との差は著しくな る. WC-Co 系超硬合金を除けば, $\mathrm{Si}_{3} \mathrm{~N}_{4}$ や $\mathrm{SiC}$ が比較

\begin{tabular}{|c|c|c|}
\hline 材 & $\begin{array}{l}\text { 降 伏 点 } \\
\left(\mathrm{MN} / \mathrm{m}^{2}\right)\end{array}$ & $\begin{array}{c}\text { 破壞靶性 } \\
K_{\mathrm{Ic}}\left(\mathrm{MN} / \mathrm{m}^{3 / 2}\right)\end{array}$ \\
\hline マルエージ龬 (300 ksi 級) & 1960 & 56 \\
\hline マルエージ鋼 (250 ksi 級) & 1774 & 74 \\
\hline AISI 4340 鋼 & 1813 & 47 \\
\hline 低強度炭素鋼 & 235 & $>217$ \\
\hline チタ カウム合金 (6A1-4V) & 1098 & 38 \\
\hline $\begin{array}{l}\text { 高力アルミニウム合金 } \\
(2024-T 3)\end{array}$ & 392 & 34 \\
\hline
\end{tabular}

表 2 各種セラミックスの破壊靱性 ${ }^{(11) \sim(15)}$.

\begin{tabular}{l|c|c}
\hline \hline \multicolumn{1}{c|}{ 材 } & $\begin{array}{c}\text { 硬 } \\
H_{\mathrm{v}}\left(\mathrm{MN} / \mathrm{m}^{2}\right)\end{array}$ & $\begin{array}{c}\text { 度 } \\
K_{\mathrm{c}}\left(\mathrm{MN} / \mathrm{m}^{3 / 2}\right)\end{array}$ \\
\hline $\mathrm{KCl}$ (s.c.) & 95 & 0.3 \\
$\mathrm{NaCl}$ (s.c.) & 240 & 0.5 \\
$\mathrm{ZnSe}$ (v.d.) & 1100 & 0.9 \\
$\mathrm{ZnS}$ (v.d.) & 1900 & 1.0 \\
$\mathrm{MgF}_{2}$ (h.p.) & 5800 & 0.9 \\
$\mathrm{SiO}_{2}$ (ガラス) & 6200 & 0.7 \\
$\mathrm{Ge}$ (s.c.) & 9000 & 0.46 \\
$\mathrm{MgO}$ (h.p.) & 9200 & 1.2 \\
$\mathrm{ZrO}$ (Ca) & 10000 & 7.6 \\
$\mathrm{Si}$ (s.c.) & 10000 & 0.6 \\
$\mathrm{WC}$ (Co) & $13000 \sim 19000$ & $12 \sim 16$ \\
$\mathrm{Al}_{2} \mathrm{O}_{3}$ (h.p.) & $12000 \sim 20000$ & $2.9 \sim 4.6$ \\
$\mathrm{Al}_{2} \mathrm{O}_{3}$ (サファイア) & 23000 & 2.1 \\
$\mathrm{Si}_{3} \mathrm{~N}_{4}$ (h.p.) & $14100 \sim 18500$ & $4 \sim 5$ \\
$\mathrm{SiC}_{\text {(h.p.) }}$ & $19000 \sim 24000$ & $3 \sim 4$ \\
$\mathrm{BC}_{\text {(h.p.) }}$ & 72200 & 6.0 \\
$\mathrm{~B}_{4} \mathrm{C}$ (h.p.) & 77000 & 6.0 \\
\hline
\end{tabular}

s.c. : 単結晶, v.d. : 気相法, h.p. : ホットプレス 法, $\mathrm{Ca}$ : カルシウム安定化, Co：コバルト結合

表 3 金属材料の破壊靶性の代表例 ${ }^{(6)}$. 
的高い值を有しており，その高硬度特性などを考え合わ せると，両材料が高強度セラミックスとして期待されて いる理由の 1 つが理解される。

破壞䩲性は材料固有の值と言えるが，気孔率や粒界， 粒径, 焼結助剂, 不純物, 加工損傷などの内的因子と, 板厚, 多軸応力, 試験温度, 試験速度などの外的因子の 影響をうける。図 7 は $\mathrm{Al}_{2} \mathrm{O}_{3}-\mathrm{TiC}$ のット・プレス材 の $K_{\text {Ic }}$ に対する試験温度の影響を調べた例である。 $K_{\text {Ic }}$ は約 $1073 \mathrm{~K}$ まではほぼ一定の值を示しているが, 1173 $\mathrm{K}$ 付近から急激に上昇し, $1473 \mathrm{~K}$ に至ると再び低下する 傾向を示している. この $1273 \mathrm{~K}$ 付近の $K_{\mathrm{Ic}}$ の増加は, ガラス質の粒界相が延性化するためと考えられる。最 近, $\mathrm{Si}_{3} \mathrm{~N}_{4}$ 焼結体の粒界に存在する第 2 相の軟化による $K_{\text {Ic }}$ への影響について,興味深い報告 ${ }^{(16)}$ がなされている. すなわち, 図8に示すように, 通常のホット・プレス材

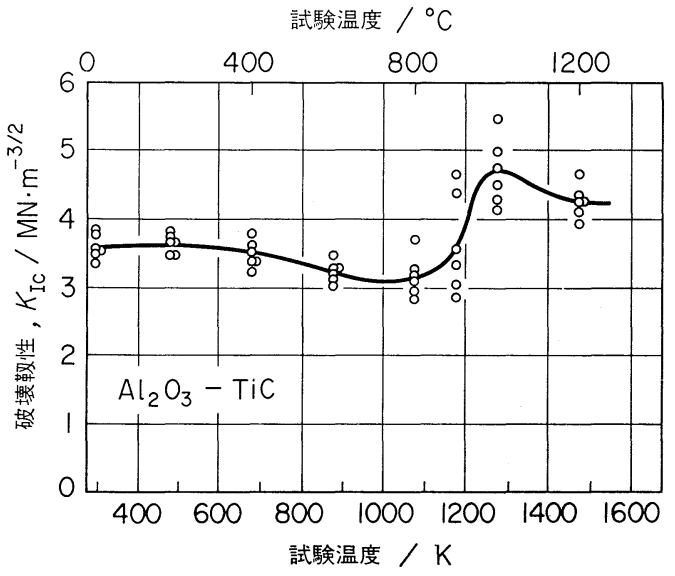

図 $7 \mathrm{Al}_{2} \mathrm{O}_{3}$ - TiC の $K_{\text {Ic }}$ に及ぼす試験温度の影響 (上田，杉田).

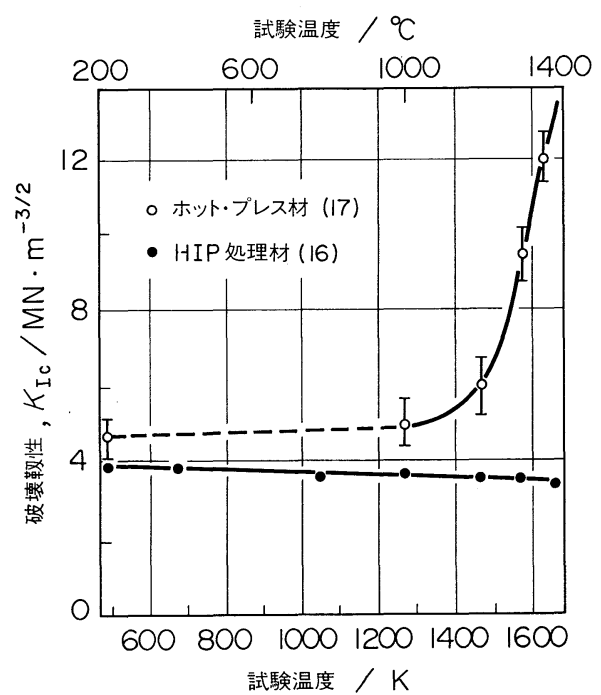

図 $8 \mathrm{Si}_{3} \mathrm{~N}_{4}$ の $K_{\mathrm{Ic}}$ の温度依存性に対する焼結助剂 の影響(16)(17).
では $1473 \mathrm{~K}$ 付近で $K_{\mathrm{Ic}}$ が急激に増加する(17)のに対し， 助剂無添加の HIP 処理材は室温から $1673 \mathrm{~K}$ に至るまで ほとんど変化せず，これは助剤添加による粒界第 2 相の 影響がないためと指摘している。

さらに, 図 $9^{(18)}$ は $\mathrm{Al}_{2} \mathrm{O}_{3}$ に分散させた $\mathrm{ZrO}_{2}$ 粒子の $K_{\mathrm{Ic}}$ に対する影響を示したものである。 $\mathrm{ZrO}_{2}$ の分散に より $\mathrm{Al}_{2} \mathrm{O}_{3}$ の $K_{\mathrm{Ic}}$ は増加し, ある体積率でピーク值を示 している.これは, 切欠き先端でのマイクロ・クラック によるエネルギ吸収に起因するものとしている。すなわ ち, $\mathrm{ZrO}_{2}$ 量が増加するとその開口之成長, 分枝に関与 するマイクロ・クラックの存在密度が増加して $K_{\mathrm{Ic}}$ を増 加せしめるが, $\mathrm{ZrO}_{2}$ がある量を越えると粒子間でマイ クロ・クラックが合体しやすくなるため $K_{\text {Ic }}$ は低下する と説明している．以上のほか，ガラスに A1 を添加して 靱性の改善を計る研究 ${ }^{(19)}$ や, $\mathrm{SiC}$ の酸化雲囲気中の焼 鈍による $K_{\text {Ic }}$ の変化の検討 ${ }^{(20)}$ など, 興味深い研究が進 められている。

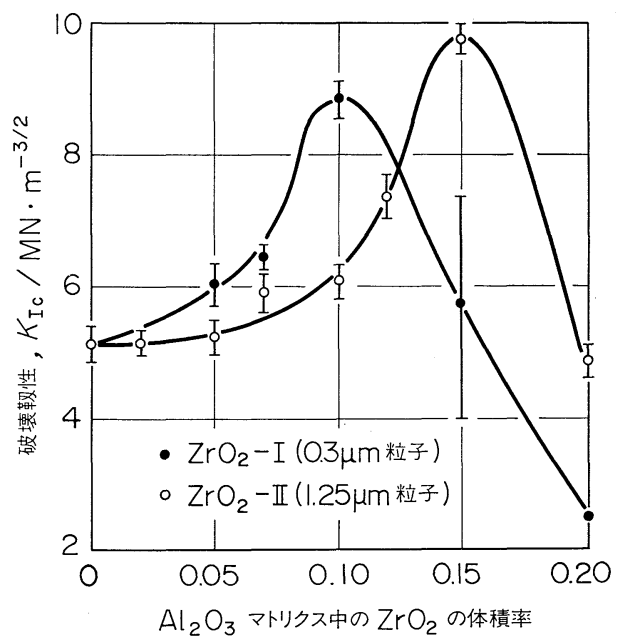

図 $9 \mathrm{ZrO}_{2}$ 粒子分散による $\mathrm{Al}_{2} \mathrm{O}_{3}$ の $K_{\mathrm{Ic}}$ の変化 ${ }^{(18)}$.

\section{（4）き裂成長速度}

活性環境ないしは腐食性環境のもとで, 静荷重をうけ てき裂が成長し破壊に至る, いわゆる応力腐食破壊と呼 ばれる現象は, $\mathrm{SiO}_{2}$ や $\mathrm{Al}_{2} \mathrm{O}_{3}$ などの酸化物系セラミック スに括いてしばしば観察される，図 10 はき裂成長の様 子を概念的に示したものであり， $K_{\mathrm{I}}-V$ 曲線と呼ばれる. ただし， $V=\mathrm{d} a / \mathrm{d} t$ はき裂成長速度である. 同図の領域 I では $K_{\mathrm{I}}$ が下限界応力拡大係数 $K_{\mathrm{ISCC}}$ に達した後 $V$ は

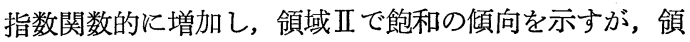
域IIに拉いては再び $K_{I}$ に依存して加速され, 破壊靶性 $K_{\text {Ic }}$ に近づくに従い急速に伝播する。図 $11^{(21)}$ は $\mathrm{Al}_{2} \mathrm{O}_{3}$ に対しての測定例である. 空気中の水分の影響を強く受 け，Vは領域Iでは化学反応速度に支配され，また，領 域IIではき裂先端への水分の拡散速度に依存すると理解 


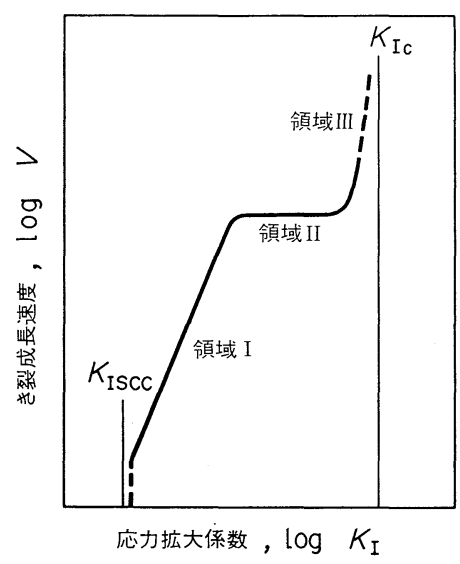

図 10 応力腐食破壊に拈ける $K_{\mathrm{I}}-V$ 曲線の概念図.

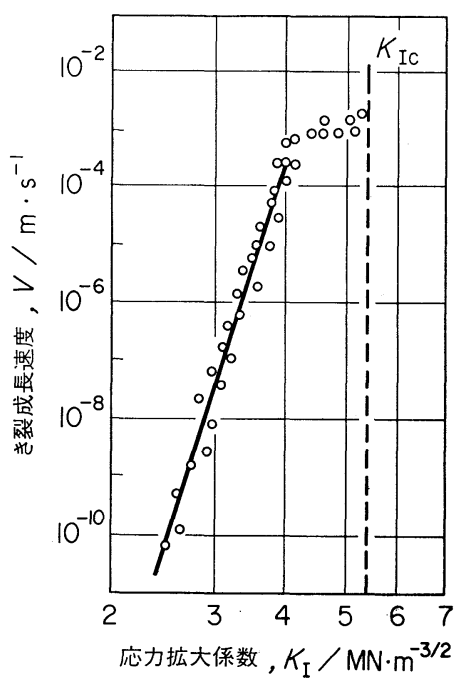

図11 $\mathrm{Al}_{2} \mathrm{O}_{3}$ の応力腐食破壊に打ける $K_{\mathrm{I}}$ と $V$ の 関係 ${ }^{(21)}$.

されている，領域而では水分の影響はほとんぞ受けず， 領域Iに比べて急勾配の材料固有の進展挙動を示すもの とされている。

ところで，図 11 のような $K_{\mathrm{I}}-V$ 関係が得られている と, 不安定破壞に至るまでの時間, すなわち, 寿命を予 測することができる。 $\mathrm{d} a / \mathrm{d} t=V$ であるから，寿命 $T$ は 次式で求められる.

$$
T=\int_{a_{0}}^{a_{\mathrm{c}}} \frac{1}{V} \mathrm{~d} a
$$

ここで， $a_{0}$ は初期き裂長さ， $a_{\mathrm{c}}$ は限界き裂長さである。 また， $K_{\mathrm{I}}$ は式（５）で表わされる場合が多く，

$$
\mathrm{d} a=\frac{2 K_{\mathrm{I}}}{Y^{2} \sigma^{2}} \mathrm{~d} K_{\mathrm{I}}
$$

となる。従って, 式(18)は次のようになる.

$$
T=\frac{2}{Y^{2} \sigma^{2}} \int_{K_{\mathrm{ISCC}}}^{K_{\mathrm{Ic}}} \frac{K_{\mathrm{I}}}{V} \mathrm{~d} K_{\mathrm{I}}
$$

次に, 図 11 のような測定から $V$ の関数が既知である
とする. 今, 簡単のために, 領域 Iが支配的である場合 を考光ると, $V=\alpha K_{\mathrm{I}}^{\beta}$ と近似できるから，式(20)は積 分可能となり，

$$
T=\frac{2}{Y^{2} \sigma^{2} \alpha(\beta-2)}\left(K_{\mathrm{ISCC}^{2-\beta}}-K_{\mathrm{Ic}^{2-\beta}}\right)
$$

が得られる。

同様な考えで, 繰り返し荷重下に怙ける疲労き裂成長 速度 $\mathrm{d} a / \mathrm{d} N=f(\Delta K)$ が既知であれば，次式によって疲労 寿命が求められることになる。

$$
N=\int_{a_{0}}^{a_{\mathrm{c}}} \frac{1}{f(\Delta K)} \mathrm{d} a
$$

ここで, $N$ は繰り返し回数, $\Delta K$ は荷重変動に対応する 応力拡大係数の変動幅である.ただし，七ラミックスに 対しては, その疲労挙動(22)の解明が重要であるにもか かわらず $\mathrm{d} a / \mathrm{d} N=f(\Delta K)$ はほとんど測定されていない ようである。上記の式(21)，あるいは，式(22) は寿命予 測を与えるものとして設計上有益な指針を示するのであ る.

\section{4. セラミックエ具の脆性損傷に対する破壊力学の 適用之解析例}

切削工具用セラミックス ${ }^{(23)(24)}$ は，セラミックスが実 用的，工業的に最も普及している分野の 1 つと言兄る. これは, 酸化物や炭化物, 矹化物などの優れた耐摩耗 性 ${ }^{(25)}$ 之耐熱性が金属系の切削工具ではなし得ない高 速切削加工を可能ならしめたからである。しかしなが ら，勒性に劣るといら性質のために，その使用範囲には 制限があり，現在種々の検討がなされている。本項で は, セラミック工具の脆性損傷に対して破壊力学理論を 適用した解析例を示寸。

(1) 解析アルゴリズムの概要

チッピングや欠損なぞの，切削工具のいわゆる脆性損 傷に执いては, 材料の微視的構造 ${ }^{(26)}$, 特に, き裂の挙 動が重要な役割(27)を演じていると考兄られる。ここで は, セラミック工具の脆性損傷は, 切削系の力学的環境 のもとで工具内のき裂が成長して不安定伝播に至った時 ひき起こされるものと考光, 脆性損傷の発生する安全一 危険境界や工具寿命を解析する ${ }^{(28)(29)}$.

図 12 は解析アルゴリズムの概略を示す，入力として の切削条件と工具材料物性飞対して応力解析を行い, き裂先端近傍の降伏域が小規模であれば, 線形破壊力学 パラメータとしての $K$ あるいは $\mathscr{G}$ を用いることにな る. 次に, 前述の破壊靱性試験で求められた $K_{\mathrm{c}}, \mathscr{G}_{\mathrm{c}}$ を 用いて破壊発生の判定を行う。すなわち, 式(9)ある いは式(10)が満たされた場合には，き裂は負荷の増加な しに不安定伝播を起こし, 工具の欠損に至る。この不安 定破壊条件を満足するかしないかは，もちろん，その時 


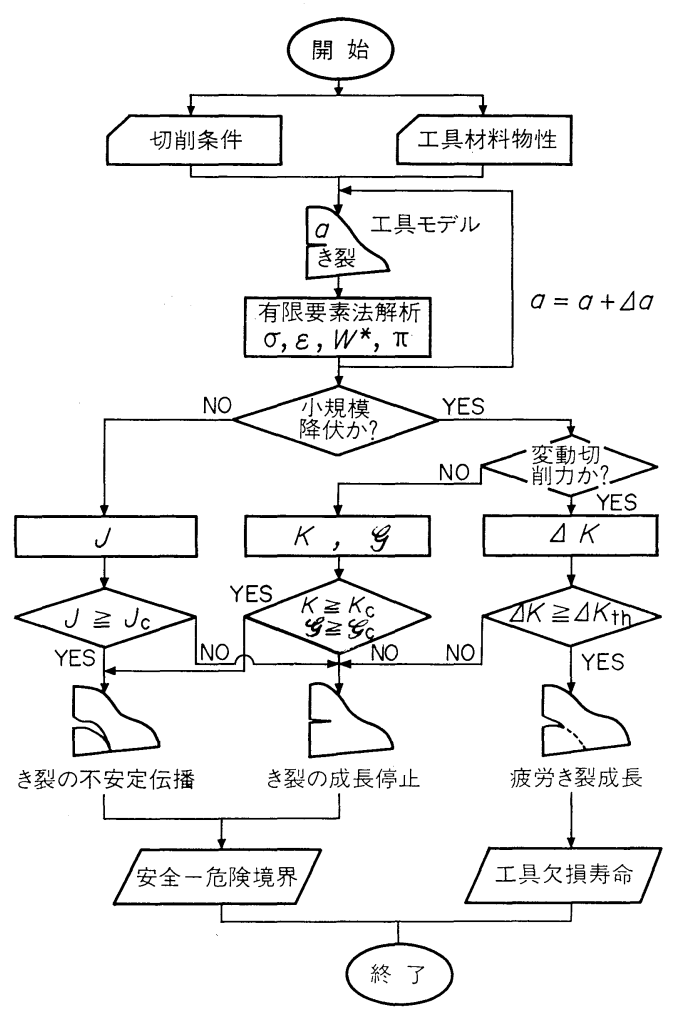

図 12 解析アルゴリズムの概要 ${ }^{(29)}$.

の切削条件, 工具形状, 材料物性, 拉よび破壊勒性によ って支配されるわけであるから，それらの諸要因に対し て安全一危険境界が求められることになる。 また, 繰り 返し負荷のかかる断続切削や不連続型切りくず生成の ような問題 ${ }^{(30)}$ 飞は， $\Delta K$ が力学的パラメータとなり，大 規模降伏の場合には $J$ 積分值が力学的パラメータとな る。ささらに，切削熱の影響を考慮する場合には ${ }^{(31)}$, 工具 内の温度分布を求め, 熱応力を算出し, 重权合わせの原 理により $K$ を解析すればよいことになる。

次に, 初期欠損の場合についての具体的な解析手順を 示す. 切削工具のように複雑な幾何学的形状と力学的境

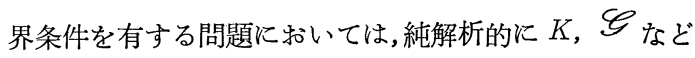
を求めることはできず，数值計算によらざるを得ない． 応力分布や变位分布より式 (2),(3) 亿基づいて求める

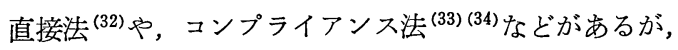
ここでは有限要素法を援用したひずみエネルギ法を適用 した，荷重拘束のもとでは，ポテンシャル・エネルギの 減少 $\mathrm{d} \pi$ はひずみエネルギの増加 $\mathrm{d} W$ に等しくなるか ら，ポテンシャル・エネルギ解放率 $\mathscr{G}$ は次式で与兄ら れる。

$$
\mathscr{C}=-\frac{\partial \pi}{\partial A}=\frac{\partial W}{\partial A}
$$

ひずみェネルギ密度を $W^{*}$ とすると，式(23)は，

$$
\mathscr{G}=\iiint_{V} \frac{\partial W^{*}}{\partial A} \mathrm{~d} V
$$

となる。ただし， $\mathrm{d} V$ は微小体積要素である。

一方，不安定破壊の発生条件は式 (9)で表わされるか ら, 式(24)を用いて

$$
\iiint_{V} \frac{\partial W^{*}}{\partial A} \mathrm{~d} V \geqq g_{\mathrm{c}}
$$

が得られる。また，小規模降伏に拈いて，モードIが支 配的な平面ひずみ問題に対しては，式(7)を用いて, $\mathscr{G}=K_{\mathrm{I}}^{2}\left(1-\nu^{2}\right) / E$ が成立するから式(25)は次のように なる、ただし，Eはヤング率である。

$$
\left\{\frac{E}{1-\nu^{2}} \iiint_{V} \frac{\partial W^{*}}{\partial A} \mathrm{~d} V\right\}^{1 / 2} \geqq K_{\mathrm{Ic}}
$$

式(26) が対象とする切削条件, 工具形状, 材料物性, お よび，破壊鞄性 $K_{\mathrm{Ic}}$ に対して，脆性損傷の発生する安 全一危険境界を与光ることになる。

\section{（2）解 析 例}

有限要素解析モデルの図示は省略するが，初期き裂に ついては，実際に生じるすくい面き裂の形態観察などに 基づき, 最大主応力の生じる場所位置するき裂が最も 成長・伝播しやすいと仮定し，また，その成長方向が最 大主応力方向に直角な 2 次元き裂であると仮定してい る。材料物性値としては, 焼結 $\mathrm{Al}_{2} \mathrm{O}_{3}$ を想定して, ヤン グ率 $E=3.1 \times 10^{5} \mathrm{MN} / \mathrm{m}^{2}$, ポアソン比 $\nu=0.2$ とし, 平 面ひずみ条件のもとで解析した。

図 13 は解析結果の 1 例であり, 安全一危険境界に対 する $K_{\mathrm{Ic}}$ の影響を示したものである，前項 3 でも述べ たように，KIc は気孔率や粒径, 粒界相, さらに, 試験 温度などの各種要因に依存して変化し, 焼結 $\mathrm{Al}_{2} \mathrm{O}_{3}$ の場 合も約 $3 \sim 5 \mathrm{MN} / \mathrm{m}^{3 / 2}$ と変化する。図 13 から明らかな

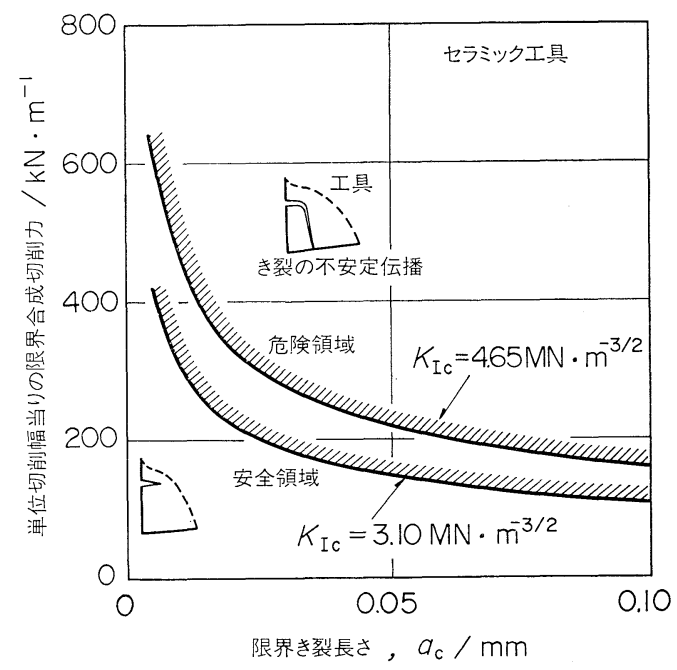

図 13 安全一危険境界に及ぼす破壊靱性 $K_{\mathrm{Ic}}$ の影 響の解析例(すくい面分布荷重 ${ }^{(29)}$ ， 
ように，安全－危険境界は $K_{\text {Ic }}$ に大きく依存し， $K_{\text {Ic }}$ が 増加するに従い, 安全領域が拡大するのがわかる.

次に, 合成切削力が刃先に集中荷重としてかかる場合 の, 切削力方向 $\left(\theta=\tan ^{-1}\right.$ 背分力/主分力) の影響を求め たのが図 14 である. $\theta$ の減少とともに危険領域が拡大 している。例えば, $\theta$ が $20^{\circ}$ から $-10^{\circ}$ に減少するに従 い,き裂長さ $50 \mu \mathrm{m}$ に打いて, 安全領域は $1 / 3$ 以下に減 少している.通常, 定常切削状態に打いては $\theta$ は比較的大 きな值を示すが，切削開始時や終了時の過渡的切削状態 や，断続切削や不連続型切りくずを生成する非定常切削 状態の際には， $\theta$ が変動するため, 危険領域に入る可能 性が高くなることが示唆される。

さらに，図 15 は式(22)を用いて，断続切削に和ける 欠損寿命を WC-Co 系超硬合金に対して求めた例であ る. 合成切削力の変動幅が増大するに従い, 欠損に至る 繰り返し切削数が減少しているのがわかる. 図 15 の傾 向は, 図13,14とともに, 実際の被削性試験で得られ

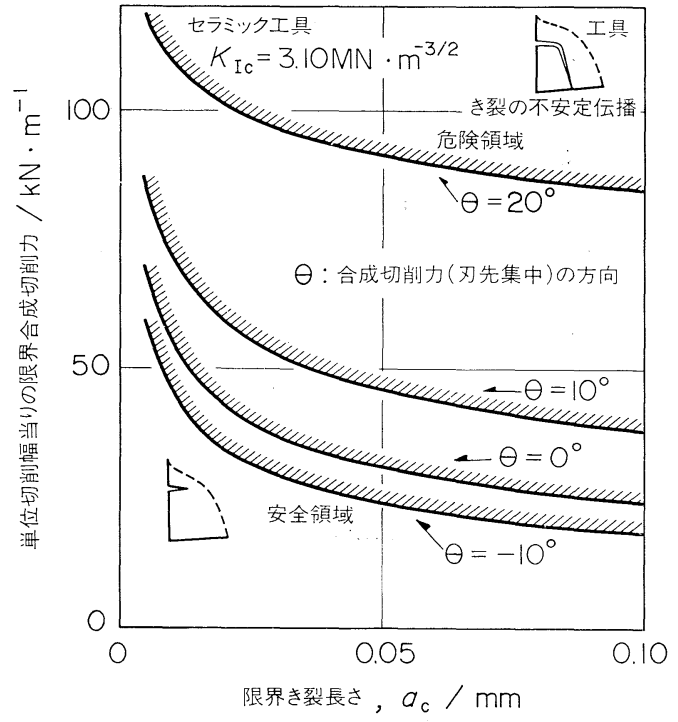

図 14 安全-危険境界に及ぽす合成切削力方向の影響 (文先集中荷重) ${ }^{(29)}$.

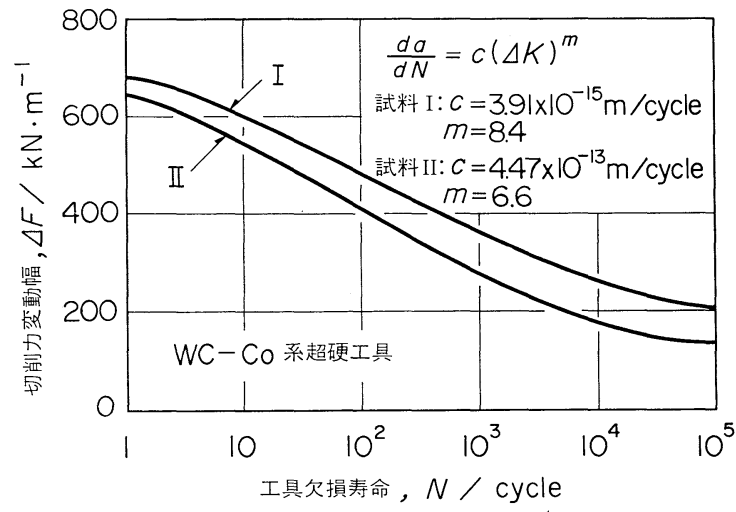

図 15 工具欠損寿命の解析例 ${ }^{(30)}$.
る久損寿命曲線や経験的知識とよく対応している。

このように, 破壊力学理論を適用して, 諸因子の効果 を詳細にとらえることにより，一方では材料の設計改善 に対して，他方では最適切削条件の選定に対して有益な 指針を与えることができると言える。このことは，もち ろん，切削工具材料に対して限られることではなく，広 く，構造材料や機械部品などの設計とその使用条件の選 定に拈いても基本的には同様の考えですすめることがで きよう。

\section{5.おわりに}

本稿では, セラミックスの破壊靶性評価に関して, 破 壊力学の基礎的事項を概説し，破壊勒性試験とその代表 例を紹介するとともに，七ラミック工具の脆性損傷に対 して破壊力学理論を適用した解析例を示した。はじめに も述べたよらに，七ラミックスへ破壊力学が適用された のは比較的最近のことであり，特に我が国ではアメリカ やイギリスに比べて，かなり立ら遅れているように思わ れる. 今後は, 次々と生み出されて来る新しいセラミッ クスに対する破壊靶性の評価，および，その材料設計へ のフィード・バック,さらに, 使用時の機能評価との関 連の検討などの研究が望まれるところであり，小文が何 らかの参考になれば幸いである。

なお，言い足りぬ点や思わ姡解があったとすれば， それはひたすら筆者らの浅学のゆえであり，ご叱責を甘 受する次第である。また，紙面の都合上ふれることので きなかったセラミックスの基礎物性 (1)(2)(35)，機械的性 質一般 ${ }^{(4)(36)(37)}$, 強度の統計的評価 ${ }^{(38) \sim(40)}$ などについて は優れた著書·文献があるので，それらを参考にされた い. 最後に，データを引用させて頂いた多くの研究者の 万々には，厚く感謝申し上げるものである。

\section{文献}

(1) 小泉光恵: ニューセラミックス, ニューセラミッ クス兓話会編, 日刊工業新聞社, (1977), 1 .

(2) 素木洋一: ファインセラミクス, エレセラ出版委 員会編，技献, (1981) , 1 .

（3）日本金属学会教育に関する委員会 : 金属学の未来 像, (1980), 27.

(4) R.W.Davidge : Mechanical Behaviour of Ceramics, Cambridge University Press, Cambridge, (1979) , 2.

(5) G.R.Irwin : J.Appl. Mech., 24 (1957) , 361.

（6）岡村弘之: 線形破壊力学入門, 培風館, (1976).

(7) J.F.Knott 著, 宮本 博 訳: 破壊力学の基礎, 培風館, (1977).

(8) J. R. Rice : Int. J.Fracture Mechanics, 2-2 (1966) , 426.

(9) Annual Book of ASTM Standards, Part.31 (1972) , 955.

(10) N.Ingelstrom and H.Nordberg : Eng. Fract. Mech., 6(1974), 597. 
(11) A.G.Evans and E.A.Charles: J.Am. Ceram. Soc., 59 (1976) , 371.

(12) B.R.Lawn and D.B.Marsha11 : J.Am. Ceram. Soc., 62 (1979) , 347.

(13) J.T.Hagan : J.Mater. Sci., 14 (1979), 2975.

(14) G.R.Anstis, P.Chantikul, B.R.Lawn and D. B. Marshall : J.Am. Ceram. Soc., 64 (1981) , 533.

(15) J.Lankford and D.L.Daridson: J.Mater. Sci., $14(1979), 1662$.

(16) A.Tanaka, M.Shimada and M.Koizumi : J. Am. Ceram. Soc., 65 (1982), 印刷中.

(17) A.G.Evans and S.M.Wiederhorm : J.Mater. Sci., 9 (1974), 270.

(18) N.Claussen : J.Am. Ceram. Soc., 59 (1976), 49.

(19) V.V.Krstic and P.S.Nicholson : J.Am.Ceram. Soc., 64 (1981) , 499.

(20) J.J.Petrovic and L.A.Jacobson : J.Am.Ceram. Soc., $59(1976), 34$.

(21) A.G.Evans : J.Mater. Sci., 7 (1972), 1137.

(22) 杉田忠彰, 佐野幸雄, 山田 巌 : 精密機械, 34 (1968), 195.

(23) 古川満彦: 精密機械, 46 (1980)，541.

(24) 䲨野雄一郎, 原 昭夫 : 精密機械, 46 (1980), 560 .

（25）杉田忠彰：日本金属学会会報, 18(1979)，186.

（26）岩田一明, 上田完次, 橋本英文, 柴坂敏郎: 精密 機械， 47 (1981)，1451。

(27) 杉田忠彰, 山田 厳: 精密機械, 30(1964), 662.
(28) K.Ueda, J.H.Percy and K.Iwata : Proc. Int. Conf. Prod. Eng., 3 (1980), 462.

（29）上田完次，杉田忠彰：粉体粉末治金協会講演概要 集, $(1980 \cdot 11$ 月), 22 .

(30) 柴坂敏郎, 橋本英文, 岩田一明, 上田完次 : 精機 学会講演論文集, (1981·11月), 70 .

(31) 柴坂敏郎, 橋本英文, 岩田一明, 上田完次 : 精機 学会講演論文集, (1981·3 月), 7.

(32) S.K.Chan, I.S.Tuba and W.K.Wilson : Eng. Frac. Mech., 2(1970), 77.

(33) H.Okamura, K.Watanabe and T.Takano: ASTM STP 536, (1972), 423.

(34) 上田完次, 岩田一明, 柴坂敏郎, J.Percy : 精機 学会講演論文集, (1980.3 月), 67.

(35) W.D.Kingery, H.K.Bowen, D.R.Uhlmann 著, 小松和蔵, 佐多敏之, 守吉佑介, 北澤宏一, 植松 敬三 共訳 : セラミックス材料科学入門,内田老鶴 圃新社, (1980).

(36) 浜野健也：セラミックス基礎工学講座, 講座小委 員会編, セラミックス, (1976), 565 .

(37) R. C. Bradt, D. P. H. Hasselman and F. F. Lange : Fracture Mechanics of Ceramics, Plenum, New York, (1977).

（38）横堀武夫：材料強度学, 岩波全書, (1974).

(39) 岡村弘之, 板垣 浩: 強度の統計的取扱い, 培風 館, (1979).

(40) E.M.Lenoe and D.M.Neal: ASTM STP 601, (1976), 63 .

\section{学協会だより(2)}

(Powder Metallurgy International Vol.13,No.4,1981 より採録) June 7, 1982

Progress in Bioceramics, Stoke-on-Trent, U.K. (The British Ceramic Society, Shelton House, Stoke-on-Trent, ST4 ZDR) .

June 7-11, 1982

First Spanish-American Congress on Ceramics, Glas and Refractories; Torremolinos, Spain) Spanish Ceramic Society, Madrid) .

September 22-24, 1982

Fourth European Conference on Fracture (Fracture and the Role of Microstructure), Leoben, Austria (Prof. K.Maurer, Inst. Metallkunde und Werkstoffprüfung, Montanuniversität, A-8700 Leoben) .

September 28-30, 1982

Optimising Energy Usage in Mining and Metallurgy, Cambridge, U.K. (The Metals Society, 1 Carlton House Terrace, London SW1Y 5DB).

October 3-6, 1982

Annual Meeting of the International Commission on Glas, Toronto, Canada (M.K.Murthy, Ontario Research Foundation, Dept. of Glas and Ceramics, Ontario. L5K 1B3C.) .

October 25-27, 1982

Silver Jubilee Meeting of the Powder Metallurgy Joint Group Meeting, London and Eastbourne, Great Britain (The Metals Society, 1 Carlton House Terrace, London SW 1 Y 5 DB).

November 10-12, 1982

Sixth International Conference on Powder Metallurgy Brno, CSSR (Dom Techniky CSVTS, CSSR 01180 Zilina) . 